\title{
Influence of park governance on tourism development in Kinabalu Park, Malaysia Borneo
}

\author{
H. C. Goh \\ Urban and Regional Planning Department, Universiti Malaya, Malaysia
}

\begin{abstract}
Kinabalu Park is a Type II protected area according to the IUCN Protected Area management category system. It is also Malaysia's first UNESCO World Heritage Site for natural category. Since its establishment in 1964, the park has been one of the most visited protected areas in the country among the domestic and international visitors. Popular tourism activities include nature trail exploring, hot spring bathing and mountain climbing. These tourism activities have not only brought in substantial income to the park to economically justify its presence but also to support its nature conservation in an integrated manner including financial revenue generation, sharing of scientific research findings as well as environmental education. These activities also benefit the local communities living in the surrounding area by diversifying the job opportunities in the rural area. Over the years, the park has witnessed several changes in its governance with the involvement of private sector and local community in its tourism management. This series of changes have impacted both the park management and the tourism development. This paper reveals some research findings on these developments and the subsequent issues based on the timeseries study conducted in the park between 2005 and 2014. This research employs a pragmatic approach combining both the quantitative and qualitative methods in data collection and analysis. Questionnaire survey and interviews were conducted on the park visitors, mountain guides, porters and the park staff. The research reveals that, while the changes in governance support the guiding principles of sustainable tourism in the long run in terms of local participation, capacity building and multi-stakeholders involvement, the issues pertaining to the profit-oriented nature of the private sector and the increasing expectation among the visitors for better educational experience require better attention by
\end{abstract}


the park authority in order to meet its society's objectives and nature conservation through tourism development.

Keywords: sustainable tourism, protected area, World Heritage Site, mountain guides, local participation, capacity building.

\section{Governance and tourism management in protected areas}

Governance is a process whereby societies make their important decisions, determine whom they involve in that process and how they render account (Graham et al. [1]). In recent years, it has been recognised as critical aspect to ensure effective conservation and sustainable tourism in protected areas. Numerous studies on governance in protected areas have been conducted with the different focuses on the governance types [2-8].

According to Eagles [4], governance has three spheres namely political, economic and administrative. Political governance is the process of policy decision-making. Economic governance refers to the process of decision-making concerning economic aspects. Administrative governance is the implementing system of law and policy. These three spheres are dependent upon each other (UNDP [9]). On the other hand, management is the organisation and coordinator of activities of an organisation to meeting a set of objectives (Anonymous [10]). As management takes place within the framework set by governance approaches, there is an interface between governance and management.

In the context of protected areas, Dearden et al. [11] suggest that the quantity and locational factors are no longer sufficient to ensure the nature conservation. Instead, it is important to ensure that the governance is able to manage the protected areas in an effective manner and produce the desired outcomes. And that only the combination of both good governance and management can ensure the sustainable conservation of these protected areas in long run.

In approaching governance, Graham et al. [1] suggest criteria to evaluate 10 principles of governance known as public participation, consensus orientation, strategic vision, responsiveness to stakeholders, effectiveness, efficiency, accountability to the public and stakeholders, transparency, equity and rule of law. The evaluation of governance using the above criteria has been applied to natural resource management including water and forest. However, its application in protected areas is lacking. Pertaining to this, Eagles [4] suggests an approach by first amalgamating the institutional arrangements proposed by Glover and Burton [12], Graham et al. [1] and More [13] which is then articulated within the context of three elements of conservation management known as the ownership of the resources, the sources of income for management and the management body Eagles [4].

This approach has resulted in different combinations of management models based on the four ownership types, three sources of income and five alternative management bodies (Table 1). 
Table 1: Options within the elements of conservation management.

\begin{tabular}{|l|l|l|}
\hline Ownership & Income & Management body \\
\hline Government agency & Government grants & Government agency \\
\hline Non-profit corporation & Fees and charges & Parastatal \\
\hline For-profit corporation & Donations & Non-profit corporation \\
\hline Community & & For-profit corporation \\
\hline & & Community \\
\hline
\end{tabular}

Subsequently, Eagles [4] reports a total of eight management models deemed to be most commonly practiced as follows:

1. National park model - government ownership of the resource with majority of funding from societal taxes and a government agency as the manager.

2. Parastatal model - government ownership resources, majority funding from user fees and a government-owned corporation as the manager.

3. Non-profit organization model - non-profit organization model with resource ownership by a non-profit corporation, funding from user fees and management by a non-profit corporation.

4. Ecolodge model - with resource ownership by a for-profit corporation, funding from user fees and management by a for-profit corporation.

5. Public and for-profit combination model - government ownership of all resources, with management and finance undertaken by a combination of public and private organizations.

6. Public and non-profit combination model - there is government ownership of all resources, with management and finance undertaken by a combination of public and non-profit organizations.

7. Aboriginal and government model - aboriginal groups own the resources and the manager is a government agency.

8. Traditional-community model - an aboriginal community owning the resource as well as managing land and tourism operations.

By referring to the management models and the governance criteria evaluation suggested by Eagles [4], this paper aims to analyze the changing management model observed in Kinabalu Park which has then witnessed different gradation of application of the governance criteria. Subsequently, the arising issues related to tourism development resulted from the changing park governance is discussed next.

\section{Methodology}

This research employs a case study approach combining quantitative and qualitative methods. For primary data collection, questionnaire survey using stratified random sampling and unstructured interviews were conducted on the visitors, mountain guides and porters. Park officials were also interviewed by the researcher. Pilot study and pre-test were carried out prior to the actual survey. Secondary data collection includes newspaper sources, published statistics, annual reports, working papers and trusted internet sources. Secondary data was 
collected through desktop search, at resource centre of at Sabah Parks Headquarter and at the library in Park HQ. The quantitative data collected were analyzed with statistical analysis including frequency distribution, cross tabulation and chi-squared analysis with the aid of Statistical Package for Social Sciences (SPSS). Content analysis was used to analyze the qualitative data and also to present the causal inferences.

\section{Kinabalu Park at a glance}

Kinabalu Park is located on the west coast of Sabah state, on East Malaysia or Malaysia Borneo. Specifically, the park is situated at the northern tip of the Crocker Range, which forms the backbone of mainland Sabah. The park was established in 1964 following the gazettement of the Sabah National Parks Ordinance 1962. Covering an area of 75,370ha, the park is accessible via road from the capital city, Kota Kinabalu with approximately two-hour drive $(90 \mathrm{~km})$. One of the most prominent features of Kinabalu Park is Mount Kinabalu which soars up to $4,095.2 \mathrm{~m}$ in height with its rocky summit protruding through the vast forest of Borneo. Mount Kinabalu is also the highest mountain in Malaysia.

The park is managed by the Sabah Parks Board of Trustees (or Sabah parks for short) in leasehold for a period of 999 years free from all liabilities and encumbrances under the Park Enactment, 1984 (Ali et al. [14]). There are seven stations within the park namely Park Headquarters (Park HQ), Poring Hot Spring, Mesilau Nature Resort, Serinsim, Monggis, Sayap and Nalapak. Park HQ, Poring Hot Spring and Mesilau Nature Resort are the park's main stations while the rest are substations which mainly serve as outposts along the park boundaries for monitoring and enforcement purposes.

The climate in Kinabalu Park is categorized as dry season from February to May and as wet period from October to January influenced by the southwest and northeast monsoon. The average temperature in Kinabalu Park differs between substations. At an elevation of $1,560 \mathrm{~m}$ above sea level, the daily temperature at Park HQ is around $20^{\circ} \mathrm{C}$. At Mesilau Nature Resort, the temperature is slightly lower than at Park HQ, at $15-18^{\circ} \mathrm{C}$ due to the higher altitude $(2,000 \mathrm{~m}$ above sea level). Poring Hot Spring stood at an altitude of $500 \mathrm{~m}$ above sea level thus having an average temperature around $25-30^{\circ} \mathrm{C}$. The temperature at Panar Laban/Laban Rata at $3,344 \mathrm{~m}$ above sea level is recorded between $2-10^{\circ} \mathrm{c}$ and can drop below freezing point during the nights. The average annual rainfall in Park HQ is recorded at $4,000 \mathrm{~mm}$ while in Poring Hot Spring, at 2,500 $\mathrm{mm}$ (Goh [15]).

Kinabalu Park is a type II protected area according to the IUCN category system. Due to its unique values and abundant species of floras, Kinabalu Park is also recognised as the Centre of Plant Biodiversity for Southeast Asia (UNESCO [16]). There are over 5,500 plant species catalogued in the park so far, consisting of 200 families and 1,000 genera and made up about $2.5 \%$ of flora on Earth (UNESCO WHC [16]). In 2000, the park was inscribed with the status of UNESCO World Heritage Site when it meets the selection criteria ii and iv (Sabah Parks [17] and UNESCO WHC [18]). Criterion ii concerns outstanding 
examples representing significant on-going ecological and biological processes in the evolution and development of terrestrial, fresh water, coastal and marine ecosystems and communities of plants and animals, while Criterion iv concerns the most important and significant natural habitats for in-site conservation of biological diversity, including those containing threatened species of outstanding universal value from the point of view of science or conservation.

\subsection{Significance of tourism in Kinabalu Park}

Since its opening in 1964, Kinabalu Park has been popular among the visitors both the locals and from abroad. As at 2012, the park received a total of 657,027 visitors arriving recorded at its three main stations, Park HQ, Poring Hot Spring and Mesilau Nature Resort. 16.8\% were foreign visitors. Climbers are significant in Kinabalu Park, making up $8 \%$ of the park visitor arrivals or $18.9 \%$ of the visitors to Park HQ station alone. Specifically, 26\% of the foreign tourists were climbers. The statistics of 2010 show that $39.3 \%$ of the foreign visitors were climbers and $58.1 \%$ of total climbers were foreign climbers. Kinabalu Park has contributed substantial financial revenue to Sabah Parks. In 2010, the total tourism income from Kinabalu Park was recorded at RM7,884,630.00 with its highest revenue generated through climbing activities (40\%) Sabah Parks [19].

The main stations in Kinabalu Park have been planned to cater for different segments of visitor. Subsequently, the activities and facilities offered in these stations are distinctive from each other. Park HQ has been a hot spot for climbers while Poring Hot Spring is popular among the locals as a weekend recreational site. Mesilau Nature Resort which only opened for tourism in 1998 aims to cater for resort ambience seekers. Generally, the facilities provided in Kinabalu Park include accommodations, restaurants and eating places, souvenir shops, toilets, shelters, walkways, transportation services. There are multiple types of accommodation available for visitors ranging from hostels to lodges, with a total capacity of 614 guests at once. In terms of transportation, the services transfer visitors within the park, i.e., from one station to another and from the Park HQ to the climbing starting point at Timpohon Gate, as well as to outside the park, especially to other cities as requested by the visitors.

In terms of activities, Park HQ has been popular for mountain climbing, apart from the visits to the Natural History Gallery, exhibition hall, nature trails, Botanical Garden which features a successful ex-situ conservation efforts as well as slide shows. Guided walks are provided to the Botanical Garden and one of the nature trails. Mountain Torq which was introduced in 2007 is a relatively new activity offered to the park visitors. It is known as the World's highest and Asia's first via Ferrata providing mountaineering activities using protected mountain path Mountain Torq [20]. Poring Hot Spring, which is located approximately $40 \mathrm{~km}$ away from the Park HQ is the most visited station of Kinabalu Park. Poring is famous for its hot sulphur baths and is often crowded during weekends and school holidays. It is also a popular destination among climbers to relieve muscle pains and fatigue after descending from the mountain. Activities at Poring include visits to Butterfly Farm, Lowland Tropical Garden, 
Orchid Conservation Centre, Ethno-botanical Garden, Mini Botanical Garden, Bamboo Garden and Rafflesia Garden. These gardens are part of the ex-situ conservation projects.

\subsection{The evolving relationship of park, public, private and people (PPPP)}

Kinabalu Park was established in 1964 after the Sabah National Parks Ordinance No. 5 came into force in 1962. The basis for the establishment was concretized following a report by the Royal Society Kinabalu Scientific expedition in 19621964 about the need to protect the area with biodiversity significance. The park authority is Sabah Parks, a statutory body established under the Sabah state Ministry of Tourism, Culture and Environment. At site-specific level, the operation of Sabah Parks is divided into two main areas namely the Administration and Management Division and Research and Education Division.

Prior to the official gazettement, the park was known for its sacredness. The local Kadazan-Dusun people regard Mount Kinabalu as the final resting place for the deceased. The respect for the mountain has led the local people to stay away from the mountain. This partially explains the lesser conflict encountered by the state government with the local people during the process of gazetting the park and demarcating its boundary. Furthermore, there was also an informal agreement between Sabah Parks and the local communities. The park would provide job opportunities to the local people especially as mountain guides and porters, in view of the potential of Kinabalu Park in attracting climbers.

In 1984, the park's status was amended from Kinabalu National Park to Kinabalu Park in line with the replacement of the original Sabah National Parks Ordinance by Sabah Parks Enactment. This amendment was made in order to avoid the confusion over the jurisdiction of the national parks in the state of Sabah, i.e. either under the jurisdiction of the Federal Government due to the 'national' parks status or by the State Government. In the end of 1986, KOKTAS or Koperasi Serbaguna Kakitangan Taman-Taman Sabah (Multipurpose Cooperative of Sabah Parks staff) was initiated and set up by a few staff members of Sabah Parks based in Kinabalu Park. They foresaw the potential of making profits in the restaurant business following the development of tourism in the park and at the same time increasing the income among the park staff (KOKTAS 1994). KOKTAS had then taken over the management of restaurant business and transportation services in Kinabalu Park until 1998 when privatization takes place.

In 1998, a privatization program was introduced to the Sabah Parks' system covering Kinabalu Park HQ, Mesilau Nature Resort, Poring Hot Spring, Manukan Island of Tunku Abdul Rahman Park. The operations of accommodation facilities previously managed by Sabah Parks, restaurants and souvenir shops were then transferred to the private sector. The introduction of privatization program was to support the socio-economic principles of sustainable tourism development promoted in the national 5-year plans. Specifically, it aims to improve the quality of tourism facilities in protected areas, to reduce the administrative, manpower and financial burden of Sabah 
Parks which subsequently enables Sabah Parks to focus on its conservation efforts and to provide job opportunities for local communities in tourism-related activities. Today, the private operator managing the facilities is known as Sutera Sanctuary Lodges.

The presence of local people in Kinabalu Park is seen through working as mountain guides and porters since the 1960s. As stated in the Park Enactment No. 10 of 2002, all mountain climbers are compulsory to hire a mountain guide. The mountain guides and porters are recruited from the nearby villages. The guide statistics witnessed an increase from approximately 20 guides in 1978 to 171 in 2005, and 193 in 2013. Working as mountain guides and porters provide the local people with an alternative income to complement their main source of livelihood through traditional farming activities. It is believed that the involvement of local communities in the tourism sector has helped to enhance the park protection. The management of the mountain guides and porters fell solely under Sabah Parks until the setup of the Kinabalu Mountain Guide Association in 2011. The association aims to represent the mountain guides and porters who render services to the climbers. Since then, the arrangement of guiding services and the management of guides have been co-handled by Sabah Parks and also the association. Until 2013, there were a total of 193 mountain guides and 118 porters registered in the park. In the same year, the female guides were also officially recruited for the first time since 1964, which not only signifies the respond to the rising demand by the climbers but also the more balance gender involvement in park tourism.

\section{The impacts of evolving PPPP on tourism development}

The management model of Kinabalu Park in the early years was the national park model which is known for its consensus orientation, strong strategic vision. Equitable is seen as being one of the strength of this model (Runte [21]). The reliance on government funding for management is the most equitable approach for most citizens (More [22]). Further to that, the job opportunities as mountain guides and porters are significant in diversifying the livelihood of the local people living surrounding the park.

Bruner et al. [23] and Dixon and Sherman [24] suggest that national park model is also able to provide conservation effectiveness. In fact, Kinabalu Park was named by the journal 'Asia Week' one of Asia's best managed forest reserves in 2000, the same year when the park was inscribed to the World Heritage Sites' list (Goh [15]). Nevertheless, this model has been criticized for unresponsive mainly due to the heavy bureaucracy typical to the public administration. Subsequently, the direct provision of recreation and tourism services under this model become high cost and inflexible (Crompton [25]). When tourism facilities were managed by Sabah Parks, complaints were received from the park visitors about the maintenance and management of accommodation facilities in the 1980s and 1990s (Goh [15]). This may have served as the main reason leading to the introduction of privatization program in Kinabalu Park. 
The management model in Kinabalu Park was changed to public and forprofit combination model in 1998 when a 30-year lease was awarded to private enterprise through privatization of the park accommodation and restaurant facilities. Eagles [4] suggests that this management model shows strong levels of public participation because the government agency involves the public through public involvement programs such as research and educational programs while the private companies involving their clients by obtaining feedbacks through surveys and market studies.

This model also shows strong consensus orientation, strong strategic vision and strong responsiveness mainly because both the government and private sectors complement each other in various areas of park management. Tourism businesses which require quick market respond are left to the private sector while the nature conservation which requires accountability is still managed by public sector. This then leads to the high financial efficiency. Satisfaction over the tourism facilities including accommodation and eatery services conducted in the park based on the visitor feedback survey in 2005 confirmed the improved satisfaction level among the repeat park visitors on the tourism facilities (Goh [15]).

The criticism received by this model is associated with the accountability and the transparency as private companies may lobby politicians to avoid being fully accountable for their contracts with the park authority (Eagles et al. [26]). This concern was observed in Kinabalu Park when the private operator, Sutera Sanctuary Lodges did not provide the data concerning length of stay of the resort guests to Sabah Parks despite of several reminders given. Further to that, there was no coordination between the operator and Sabah Parks when it came to the accommodation booking handled by the operator and the issuance of climbing permits by Sabah Parks which had led to confusion among the climbers and several complaints were filed.

Furthermore, equity may be lowered due to the profit-making nature of the private company in providing the tourism services. Research findings by Goh and Mariney [27] revealed that there was a rising dissatisfied sentiment among the local visitors concerning the expensive costs for climbing due to the price increase by the private operator being the monopolized service provider. Partitions were signed by the local people to object the charges imposed by the private sector.

The most recent development is the setting up of Mountain Guides Association in 2011 which signifies the local participation in the park to the next level, thus making the park management model a park-public-private-people model. This development supports the societal objective of protected areas through more meaningful participation of local people in the park tourism management. Although this management model is not among the eight most widely-used models as suggested by Eagles [4], some criteria used in assessing the traditional community model was employed to explain some features applicable to the involvement of traditional community. These include the public participation, consensus orientation and responsiveness. 
The setting up of the Mountain Guide Association enhances the level of the local participation in Kinabalu Park. Instead of merely involved as service providers (mountain guiding and porter service), the local people are involved also in the decision-making and management of the services they rendered. It provides a formal channel for the members to express their opinions, to discuss and to negotiate with Sabah Parks on the wages and welfares. The association committee is able to mediate differing interests in order to reach a broad consensus on the best interests of the members before putting forward for discussion with Sabah Parks.

Weaknesses are observed in terms of responsiveness whereby the services rendered by the mountain guides have received some critical comments from the climbers in terms of communication skills, language proficiency and knowledge/information during guiding. Based on the initial findings of visitor survey conducted in 2013, these three aspects scored the lowest among the five aspects being evaluated (the other two aspects are friendliness and responsibility). These findings are similar to results in 2005 (Goh [15]). At present, training is provided by the Sabah Parks at no cost to the mountain guides in terms of first aid and the park basic information on the flora and fauna and history. While English literacy is a concern, no training is provided at the moment. According to the park personnel, English courses were offered to the mountain guides but the turnout rate was low. Therefore, it was discontinued. Another observation in the responsiveness is that, while the survey respondents rated the English literacy among the mountain guides low, more than $95 \%$ of the guides rated their English proficiency as fluent (52\%) and a bit fluent (46.3\%). Mismatch is observed between the capacity of mountain guides and the expectation among the climbers. While safety is given the priority by the climbers, there is a significant increase of expectation on educational experience by the climbers.

\section{Concluding remarks}

This paper reveals the influence of different governance approaches using the management models suggested by Eagles [4] on tourism development in Kinabalu Park. The evolution of management models in the park witnesses different set of issues experienced in its tourism management. Of which, the issues found in the park during the implementation of both national park model and public and for-profit combination model are conformed to Eagles' suggestions. The recent model which includes the local people in the management through the establishment of Mountain Guide Association has further diversified the management model portrayed in Kinabalu Park, which the author terms it as PPPP (park-public-private-people) model. Issues experienced in Eagles' traditional community model are partly observed in Kinabalu Park especially the mismatch of guides' capacity and climbers' educational expectations, which would require immediate attention. Notwithstanding this fact, as this model has only been implemented since 2011, the author suggests that this new management model in Kinabalu Park may better support the criteria 
of good governance proposed by Graham et al. [1] in meeting the principles of sustainable tourism in long term. Author also recommends the future research focusing on the monitoring of the governance influence on tourism development in the park through the time-series data collection.

\section{Acknowledgement}

This study is funded by Ministry of Education Malaysia through Fundamental Research Grant Scheme (FRGS) project number FP047-2013A.

\section{References}

[1] Graham, J., Amos, B. \& Plumptre, T. W., Governance principles for protected areas in the 21st century. Institute on Governance, Governance Principles for Protected Areas, pp. 1-2, 2003.

[2] McNeely, J., Protected area institution. Partnerships for protection: New strategies for planning and management for protected areas, ed. S. Stolton \& N. Dedley, Earth-scan: London, pp. 195-204, 1999.

[3] Buckley, R., Public and private partnerships between tourism and protected areas: The Australian situation. Journal of tourism Studies, 3(1), pp. 36-38, 2002.

[4] Eagles, P. F. J., Governance of recreation and tourism partnerships and protected areas. Journal of Sustainable Tourism, 17(2), pp. 231-248, 2009.

[5] Plummer, R. \& Fennell, D. A., Managing protected areas for sustainable tourism: Prospects for adaptive co-management. Journal of Sustainable Tourism, 17(2), pp. 149-168, 2009.

[6] Su, D., Wall, G. \& Eagles, P. F. J., Emerging governance approaches for tourism in the protected areas of China. Journal of Environmental Management, 39(6), pp. 749-759, 2007.

[7] Hovik, S., Sandstrom, C. \& Zachrisson, A., Management of protected areas in Norway and Sweden: Challenges in combining central governance and local participation. Journal of Environmental Policy \& Planning, 12(2), pp. 159-177, 2010.

[8] Eagles, P. F. J., Romagosa, F., Buteau-Duitschaever, W. C., Havitz, M., Glover, T. D. \& McCutcheon B., Good governance in protected areas: An evaluation of stakeholders' perception in British Colombia and Ontario Provincial Parks. Journal of Sustainable Tourism, 12(1), pp. 60-79, 2013.

[9] Governance. United Nation Development Programme (UNDP) Web Site. New York, http://www.un.org/Pubs/CyberSchoolBus/briefing/governance/ governance.pdf.

[10] Anonymous, Management. Business Dictionary, http://www.business dictionary.com/definition/management.html.

[11] Dearden, P., Bennett, M. \& Johnston, J., Trends in global protected area governance, 1992-2002. Journal of Environmental Management, 36(1), pp. 89-100, 2005. 
[12] Glover, T. D., Burton, T. L., Collins, M. F. \& Cooper, I. S., A model of alternative forms of public leisure services delivery. Leisure management: Issues and applications, CABI Publications, pp. 139-155, 1998.

[13] More, T., From public to private: Five concepts of park management and their consequences. The George Wright Forum, 22(2), pp. 12-20, 2005.

[14] Ali, L., Sidek, A. R. \& Nais, J., The management and development of state parks in Sabah. Proc. of the Int. Conf. on National Parks and Protected Areas, Dept. of Wildlife and National Parks, Peninsular Malaysia: Kuala Lumpur, 1990.

[15] Goh, H. C., Sustainable tourism and the influence of privatization in protected area management. A case of Kinabalu Park, Malaysia. Ecology and Development Series, 57: Bonn ZEF, 2008.

[16] World Heritage: Kinabalu Park. United Nations Educational, Scientific and Cultural Organization (UNESCO) Web Site, Paris, http://whc.unesco.org/en/list/1012.

[17] Kinabalu Park: A world heritage site? Sabah Parks proposal to be submitted to the State Cabinet, Kota Kinabalu, Sabah, 1998 (unpublished paper).

[18] New sites to be inscribed on UNESCO World Heritage List. United Nations Educational, Scientific and Cultural Organization (UNESCO) Web Site, Paris, http://whc.unesco.org/en/news/132.

[19] Sabah Parks Statement of revenue for the month January 2010 to December 2010. Sabah Parks, Kota Kinabalu, 2010.

[20] Mountain Torq Web Site, Sabah, Malaysia, http://www.mountaintorq.com/.

[21] Runte, A., National parks: The American experience, University of Nebraska Press: Lincoln, NB, 1997.

[22] More, T.A., The privatization of public lands, Proc. of the 2006 Northeastern Recreation Research Symposium, eds. R. Burns \& K. Robinson, U.S. Forest Service: Newtown Square, PA, pp. 135-141, 2007.

[23] Bruner, A., Gullison, R.E., Rice, R.E. \& da Fonseca, G., Effectiveness of parks in protecting tropical biodiversity. Science, 291, pp. 125-128, 2001.

[24] Dixon, J.A., \& Sherman, P.B., Economics of protected areas: Approaches and applications, Island: Washington, DC, 1990.

[25] Crompton, J.L., Financing and acquiring park and recreation resources. Human Kinetics: Champaign, IL, 1999.

[26] Eagles, P.F.J., McCool, S.F. \& Haynes, C., Sustainable tourism in protected areas: Guidelines for planning and management, UNEP, WTO, and IUCN: Gland, 2002.

[27] Goh, H.C. \& Mariney M.Y., Sustaining Tourism Development in Protected Areas. A Case of Kinabalu Park. International Journal of Trade, Economics and Finance, 1(2): 179-183, 2010. 